\title{
Financial Development, Financial Repression, And Growth In Developing Economies
}

\author{
Lillian Kamal, Ph.D., University of Hartford, USA
}

\begin{abstract}
Many studies have examined the relationship between economic growth and finance. A continuing question is the choice of a clear proxy for financial development. This paper attempts to elucidate this issue from a developing country perspective, while controlling for financial repression. The proxy of choice is the ratio of currency outside the banking system to real output $(C B)$. This proxy is unique in that it is related to the degree of financial repression, and thus relates differently to economic growth depending on the level of financial development. The statistics support the hypothesis of a $U$-shaped behavior of $C B$ with financial liberalization. The empirical results show that $C B$ relates negatively to growth in countries that are less financially liberalized and positively with growth in countries that are more financially liberalized. The literature has used real interest rates as a measure of financial repression. An innovative measure of financial repression is then proposed that combines the use of currency inside banks and currency outside banks, and is tested concurrently with a broad money depth measure. The study is carried out using a panel approach, and the sample is also divided into different geographical regions, in order to see whether the relationship differs between geographical regions. The study concludes that there is overwhelming evidence that financial repression, which is indicative of financial under-development, is negatively related to growth.
\end{abstract}

Keywords: Financial Development; Financial Repression; Economic Growth

\section{INTRODUCTION}

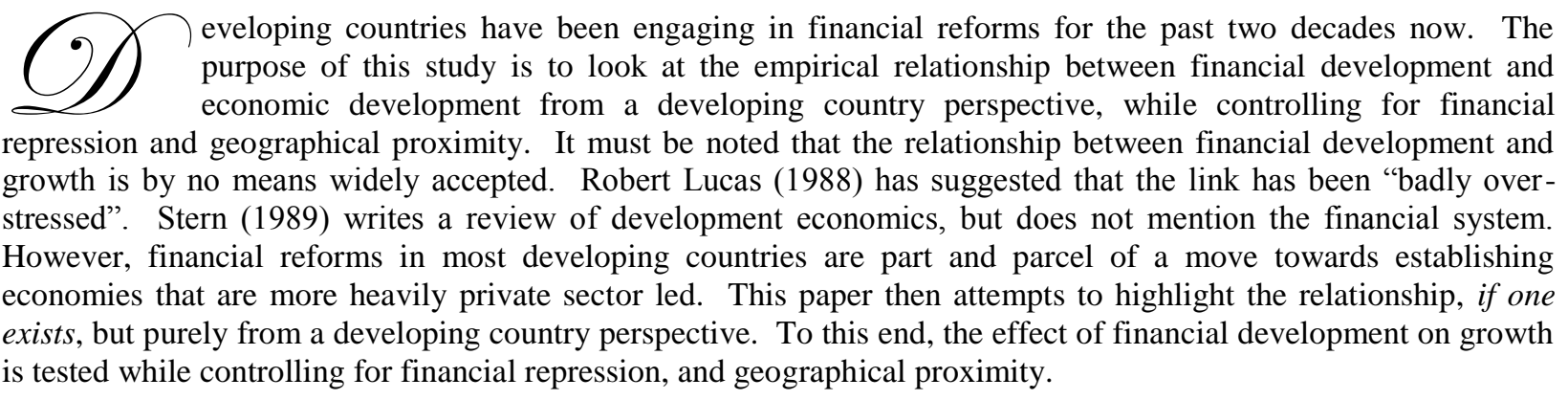

\section{THEORY}

The literature in this area is vast. The seminal work in the area was by Goldsmith (1969). In his paper, he measured the level of financial development by comparing the value of financial intermediaries' assets to gross national product. The key assumption here was that the size of the financial system has a positive correlation with the level of financial services provided. This study was carried out on 35 countries with pre-1964 data, and also did not control for other factors influencing economic growth. Goldsmith was able to find evidence that, as countries develop, the size of their banking sectors tend to become larger relative to national output. Overall, this study did 
not attempt to make any causal relationships. It simply indicated a correlation between financial development and economic development.

McKinnon (1973) and Shaw (1973) were among the first to provide a theoretical background for why financial development could cause growth. Since then the literature has looked at financial development through measures of banking activity (King and Levine, $1993 \mathrm{a}, \mathrm{b}$ ) and measures of stock market development (Atje and Jovanovic, 1993), and Levine and Zervos (1998). The continuous problem identified in the literature has been a measure that can adequately capture the degree of financial development in all its changing aspects. Several issues exist - the services provided by the financial system are diverse - these include mobilization of savings, diversification of risk, and management of the payment system. Secondly, the agents that provide these financial services are diverse - these include banks, securities markets, and insurance companies, among others (Andres, Ignacio, and Lopez-Salido, 1999). A third issue that has been tackled in a few instances in the literature is the fact that financial development also involves financial market deregulation, and this involves a reduced level of government restrictions, such as interest rate controls and price distortions in the financial sector.

What impact does the financial system theoretically have on an economy? To understand this link, one must first understand the functions that a financial system performs. Levine (1997) has listed five functions that a financial system performs. These are to enhance the mobilization of savings, the allocation of resources, portfolio diversification, the supervision of managers, and the facilitation of the exchange of goods and services. There are then two channels through which each of these financial functions can affect economic growth - the capital accumulation channel and the technological innovation channel. A financial system will alter the rate of capital accumulation by affecting the rate of savings, or by reallocating savings among new and different capital producing technologies. The financial system will also affect the rate of technological innovation and thus affect the steady state level of growth in an economy. It is expected that from a developing country perspective, development of a financial system will affect savings mobilization initially. The logic of this idea is as follows: developing countries rely on the banking system. As the financial system develops, the banking system is able to provide varied instruments that allow the mobilization of savings in new ways. Savers are then able to take advantage of better financial instruments that provide them with a better risk-return trade-off. Ultimately financial development means that savers can hold better portfolios.

But as Levine (1997) points out, financial development is also expected to affect economic growth through savings mobilization in another way. Producers in an economy that is financially under-developed do not have access to multiple investors. There exists an informational asymmetry. Thus they produce at a scale that is economically inefficient. A developed financial system provides a better opportunity for the efficient exchange of resources between savers and firms. Firms can thus expand, and increase their production. As they produce at a larger economic scale, they also become more efficient and productivity is improved, raising the rate of economic growth. As Levine (1997) puts it, financial development can "profoundly affect economic development".

Given that development of the financial sector is expected to positively impact economic growth, there are factors that are often present in developing countries that can hinder the development of the finance sector. Governments may place regulations on the financial sector in the form of price distortions and restrictions in order to maintain the financial sector as a source of public finance. Examples of restrictions that often exist in developing countries are subsidized or directed credit, credit rationing, collusive contracts between public firms and banks, and caps on interest rates (Creane, et al, 2003). These kinds of distortions in a free financial sector are commonly referred to as "financial repression". It is easy to see how financial repression would limit the functioning of the financial system and thus possibly affect investment and economic growth negatively.

Giovanni and de Melo (1993) have defined financial repression as a combination of controls on international capital flows and restrictions on domestic interest rates. Typically researchers consider financial repression to be the product of artificially set interest rates that causes real interest rates to fall well below the rates of inflation. Traditionally, domestic real interest rates (henceforth referred to as RI) are used in the literature as a measure of financial repression. Government revenue is then calculated as differential between the foreign and domestic interest rates multiplied by the amount of government debt. Giovanni and de Melo (1993) find that the revenue that governments make from financial repression is substantial and in some cases is even comparable to the 
revenue from seigniorage. It is important to note that in the absence of international financial controls, most cases of domestic controls on interest rates could be bypassed with foreign borrowing and lending. However, controls on domestic interest rates are often coupled with restrictions on international borrowing and lending and this leads to a compromised financial system.

The literature on the finance-growth relationship has utilized both the cross-sectional approach and the time series approach. Using a cross-sectional approach requires the averaging out of data over long time periods and then using the data in cross-sectional regressions that are aimed at explaining the cross-country variations in growth rates. These sorts of studies are then able to gauge the average effect of variables that affect economic growth rates. Apart from the seminal King and Levine (1993) paper, there are other studies by Gelb (1989), Roubini and Sala-i-Martin (1992), and Fry (1996) that all use a cross-sectional approach. However, cross-sectional studies have their fair share of critics. The users of this technique have themselves pointed out shortcomings with this approach. Evans (1995) refers to the econometric issues that arise with heterogeneous slope coefficients across countries. The classic paper in the finance-growth literature is the King and Levine (1993) paper - the study covers the 1960-89 period and focuses on 77 countries. The authors use various proxies for financial development, which are mostly monetary depth measures, and three growth variables (average growth rate of real GDP per capita, average growth rate of capital stock per capita, and a measure of total factor productivity). Levine's paper utilizes cross-country data, and Levine himself alludes to the problems with using this kind of data. There is the difficulty in establishing causality in cross-country data sets, and also the problem of average effects of financial development.

Time series studies have not, however, clarified the relationship between finance and growth. De Gregorio and Guidotti (1995) who discuss the pros and cons of various financial development proxies, have actually found a negative relationship between finance and growth. Recent studies have begun to use panel data techniques to examine the issue. Beck and Levine (2004) look at financial development through banks and also through the stock market. They find that stock market liquidity - this is the ratio of the total value of shares traded to market capitalization - is positively related to growth.

Pesaran and Smith (1995) have suggested that panel data techniques with averaged data may still suffer from econometric problems. Past studies have sometimes averaged data over a few years to remove business-cycle influences. This may cause the loss of information on long-run relationships. It has been suggested (Demetriades and Andrianova, 2003) that increasing data samples to forty or fifty years would make evidence from time-series utilizing techniques more conclusive, especially if the data is available in quarterly frequencies. It must be recognized, however, that in studies that involve many countries, the lack of data availability is always an important consideration. Developed countries usually have better data availability when compared to developing countries since this is a developing country study; data restrictions are of prime concern.

\section{PROXIES OF FINANCIAL DEVELOPMENT}

Chen and Fische (1993) have discussed a theoretical reasoning that suggests that currency outside the banking system may be a good inverse proxy for financial development in developing countries. They note that deposit insurance schemes do not have a very important role in developing countries which have less diversified economic bases. Depositors thus tend to shy away from the banking system. The result is that alternate informal arrangements such as savings clubs and rotating credit associations become more important in bridging the gap between the borrower and the lender. This argument provides a further theoretical basis for the choice of currency outside the banking system as an inverse proxy for financial development. The more developed a financial system, the greater the role that deposit insurance plays in the banking system, and thus the greater the amount of money within the banking system.

Moreover, real interest rates in developing countries are on average, negative. This in essence has been a characteristic of many developing countries as financially repressed economies. Standard money demand models such as the Baumol-Tobin approach indicate that money holdings are inversely related to real interest rates. Therefore if real interest rates are negative, this would indicate a low level of deposits. Financial repression, which is indicative of low financial development, is then characterized by a low ratio of deposits. Thus private sector funds are not in the banking system but outside of it. The higher the level of currency outside the banking system 
(given a financially repressed economy), the lower the level of financial development, and the more restricted the access to those funds by investment projects. This compromises the link between investment and economic growth. Thus a high ratio of currency outside the banking system should be negatively related to economic growth.

The logic behind using currency outside the banking system relative to real output as a proxy for financial development is as follows: as a country begins to develop its financial sector, the banking system develops first as an initial bridge between savers and borrowers. If there is a large amount of money outside the banking system, this would indicate that the banking sector is compromised (perhaps through financial repression) and savers do not have access to varied instruments through the banking sector. Thus a large amount of money outside the banking sector would seem to be an indicator of a lower level of financial development. Most developing countries began the process of financial development within the last three decades. More evolved methods of linkage between savers and borrowers such as mutual funds or stock markets are relatively recent introductions into these countries.

At an intermediate level of financial sector development, CB may actually fall as savers explore increased options within the banking sector and firms flock to the banks for their financing needs. However, as the level of financial sector development increases further, CB (and also deposits within the banking sector) may actually rise again as the development of institutions such as mutual funds and stock markets develop. This is a proxy that can reflect the development of a financial sector given the removal of the elements of financial repression. In countries in the initial stages of financial sector liberalization, the ratio is expected to be high, and negatively related to growth. As countries reach the intermediate stage, the ratio is expected to fall, and then as countries reach the more advanced stages of financial sector development, the ratio is expected to rise again. It must be noted of course, that financial sector development here is relative since the sample consists entirely of developing countries. In the intermediate and higher growth countries, CB is expected to become positively related to growth. Overall CB essentially fulfills the requirements of being a measure of financial development that can capture the degree of financial development in all its changing aspects. The use of $\mathrm{CB}$ as a ratio of financial development begs the use of the opposite of CB - deposits within the banking sector over GDP (henceforth referred to as DGDP) as another proxy. The results are expected to indicate the opposite relationship (when compared with $\mathrm{CB}$ ) - a positive relationship with economic growth.

Monetary depth measures have been used several times in past studies as representative of the formal size of the financial sector in an economy. Goldsmith (1969) discussed the nature of the financial sector in developing countries. Firms in developing countries resort to greater levels of self-finance than firms in developed countries. When financial instruments are issued by firms, they are primarily procured by financial institutions rather than private savers. There are few large "organized" markets for the trade of securities such as bonds, mortgages, and stocks, mostly because such markets require economies of scale that are generally not present in developing countries. There is thus limited direct contact between the savers and the borrowers and instead indirect interaction through the monetary mechanism, which is the lifeline of the financial sector. It therefore becomes reasonable to develop theoretical models where money (defined to include all deposits in the banking sector, as well as currency) is the only financial asset available to savers. (McKinnon, 1973)

Uncertainties regarding risk and return are acute in developing countries and money becomes the asset that is most risk-free and default-free for short-term transactions. Since lenders do not have access to sophisticated methods of risk-analysis (available in developed countries), financial instruments other than money cannot be well marketed. Hence money becomes the choice instrument of private capital. (McKinnon, 1973)

\section{METHODOLOGY}

Three proxies of financial development are used in this paper - CB, DGDP, and M - the choice of these measures is based on what makes logical and theoretical sense from a developing country perspective. Lack of continuous data series for developing countries limits the sample size to 32 countries. 1995 is the base year for the consumer price index data for all thirty-two countries. Raw data is transformed into the required variables of interest as follows: economic growth is calculated as the percentage change in GDP per capita; inflation is calculated as the percentage change in the consumer price index. Real interest rates are calculated using the Fisher Identity, and are the difference between the nominal rate of return on 3-6 month deposits at banks and the inflation rate. 
Currency outside the banking system (CB) is calculated as the ratio of currency outside domestic banks to nominal GDP. Banking sector deposits (DGDP) is calculated as the ratio of total deposits (including checking, time and savings deposits) in the banking sector to nominal GDP. Monetary depth (M) is the ratio of broad money (M2) to nominal GDP. All the data is procured from the World Bank's World Development Indicators, and the IMF's International Financial Statistics.

For the purposes of this study, $\mathrm{M}$ provides the standard against which other proxies are tested. Greater broad money or narrow money depth indicates greater financial deepening, and a greater size of the formal financial sector, and thus represents greater financial development. As mentioned though, these measures are prone to criticism; hence the search for more theoretically sound proxies is a worthwhile cause.

This paper proposes a new measure for financial repression that actually combines both two proxies of financial development - CB and DGDP, and creates a new variable called FR (CB/DGDP). It is proposed that the ratio of currency outside banks to currency inside banks can best proxy for financial repression. If this ratio is low, then it could reflect a banking sector where savings and lending are allotted according to market forces. This ratio would be low only if there was a marked absence of real interest rate ceilings and directed lending. This proxy is especially important for countries where there is considerable government interference in the banking sector, that is, in less liberalized countries. For example, most of the Sub-Saharan African countries still have banking sectors that are less developed than those of Asian countries, and where government still have interest rate ceilings in place. In South East Asian countries, in comparison, where financial sector liberalization has been underway for almost two decades, financial repression is less of an issue.

Table 1: Behavior of Financial Development Proxies Over Time for the Different Regions (Mean Values Over Time)

\begin{tabular}{|c|c|c|c|c|c|}
\hline $\begin{array}{l}\text { Period } \\
1970-1980\end{array}$ & $C B^{*}$ & $M^{*}$ & $D G D P^{*}$ & $R I^{* *}$ & $F R^{*}$ \\
\hline Full sample & 0.489 & 21.991 & 0.186 & -8.133 & 3.979 \\
\hline Africa & 0.477 & 21.202 & 0.171 & -5.917 & 4.849 \\
\hline Latin America & 0.402 & 18.946 & 0.199 & -23.841 & 2.367 \\
\hline South-East Asia & 0.601 & 26.745 & 0.219 & -0.678 & 2.995 \\
\hline $\begin{array}{l}\text { Period } \\
1981-1990\end{array}$ & $C B^{*}$ & $M^{*}$ & $D G D P^{*}$ & $R I^{* * *}$ & $F R^{*}$ \\
\hline Full sample & 0.496 & 28.894 & 0.236 & 3.145 & 3.225 \\
\hline Africa & 0.503 & 27.581 & 0.207 & -7.803 & 4.148 \\
\hline Latin America & 0.388 & 23.219 & 0.222 & 40.824 & 1.956 \\
\hline South-East Asia & 0.569 & 37.319 & 0.326 & 4.216 & 1.806 \\
\hline $\begin{array}{l}\text { Period } \\
1991-2002\end{array}$ & $C B *$ & $M^{*}$ & $D G D P *$ & $R I^{* *}$ & $\boldsymbol{F} \boldsymbol{R}^{*}$ \\
\hline Full sample & 0.475 & 32.256 & 0.269 & -1.762 & 3.104 \\
\hline Africa & 0.468 & 26.889 & 0.214 & -3.849 & 4.089 \\
\hline Latin America & 0.368 & 24.486 & 0.223 & 0.048 & 1.948 \\
\hline South-East Asia & 0.589 & 52.032 & 0.458 & 2.477 & 1.423 \\
\hline
\end{tabular}

In Table 1 above, $\mathrm{CB}$ is the ratio of currency outside the banking system to GDP, M is the ratio of M2 to GDP, DGDP is the ratio of banking sector deposits to GDP, RINT is the real interest rate (calculated as per the Fisher Identity), and FR is CB/DGDP. Table 1 above clearly supports the hypothesis that the CB ratios display a Ushaped characteristic in relation to the level of financial sector development. In the African and South East Asian group of countries, the CB values are consistently higher than those in the Latin American group. 
Table 2: Summary Statistics for all proxies (FD and financial repression) for full sample and regions

\begin{tabular}{|l|c|c|c|c|c|}
\hline Period 1970-2002 & $\boldsymbol{C B}^{*}$ & $\boldsymbol{M}^{*}$ & $\boldsymbol{D G D P}^{*}$ & $\boldsymbol{R I}^{* *}$ & $\boldsymbol{F R}^{*}$ \\
\hline Full sample & 0.486 & 27.815 & 0.231 & -2.398 & 3.432 \\
\hline Africa & 0.481 & 25.221 & 0.197 & -5.737 & 4.361 \\
\hline Latin America & 0.385 & 22.391 & 0.215 & 4.441 & 2.090 \\
\hline South-East Asia & 0.587 & 39.508 & 0.338 & 1.907 & 2.063 \\
\hline *Nominal values **Real values
\end{tabular}

The above descriptive statistics in Table 2 reveal some interesting facts about the relationship between financial development and financial repression. When the descriptive statistics are calculated by region, it is evident that the overall sample statistics conceal significant differences between the regions. The overall sample is heavily weighted towards the African countries, which are greater in number in the sample than the countries from the two other regions. The African sample is close to the average CB value for the full sample. South East Asia on the other hand, has a higher CB ratio than the full sample average. This is not surprising because the average South East Asian country is more financially liberalized (in terms of the availability of non-bank financial instruments and a longer existence of fully functioning stock markets) than the countries in, for example, the African sample. For the full period 1970-2002, the CB values again display the U-shaped behavior that was displayed in Table 1.

Within the banking sector, South East Asian countries also have higher ratios of DGDP reflecting not only a greater degree of economic growth (thus a greater savings ratio), but also a greater degree of saver faith and financial return in the banking sector due to less financial repression. The overall sample's statistics indicate that, on average, the African group of countries is financially repressed (reflected by negative RI). As the analysis proceeds to the Latin American and South East Asian groups of countries, the RI values on average become positive.

The new FR variable highlights the degree of financial repression even more starkly. The degree of financial repression (as measured by FR) in the African sample is more than twice that of both the Latin American and the South East Asian sample. This indicates that a very high degree of money is outside the banking sector in the African sample. In these countries, that have a lesser degree of financial development, the non-bank financial sector is rather under-developed and there are not many alternative instruments such as mutual funds or longstanding and fully functioning stock markets. Thus savers shy away from the banking sector, not only due to low economic growth (which causes a low savings rate), but also due to depressed real interest rates (as evidenced by the average negative real interest rates in the African sample). Overall then, the FR values behave as expected and on average, fall as finance become more liberalized.

It is interesting to consider the relationship between the proxies themselves, and also with investment. This relationship is not a priori clear-cut. CB could be expected to be inversely correlated with DGDP, since the higher the level of currency outside the banking sector, the lower the level of currency inside the banking sector. However, in a case where an economy is highly developed, a high level of CB could go hand in hand with an increased level of DGDP because both bank and non-bank sectors offer a multitude of options for savers. CB is expected to be positively correlated with $\mathrm{M}$, because $\mathrm{CB}$ is in effect part of $\mathrm{M}$. The proxies are expected to be positively correlated with investment due to the capital accumulation theory. Table 3 shows the averaged cross-sectional correlations between financial development and investment for the entire sample period T. As expected all the proxies are positively correlated with INV; DGDP shows the strongest correlation due to the fact that investment directly depends on the amount of deposits available for investors to borrow. The correlation between CB and DGDP is positive, possibly reflecting a greater weight from those economies further along the development spectrum. It must be noted though that since if money growth is positive, then both CB and DGDP are expected to display positive growth as well, and the positive correlation may be displaying the growth of both measures. 
Table 3: Correlation Between FD Proxies, FR and Investment

\begin{tabular}{|c|c|c|c|c|c|}
\hline & $\boldsymbol{C B}$ & $M$ & DGDP & FR & $I N V$ \\
\hline$C B$ & 1.0000 & $\begin{array}{c}0.344656 \\
(0.451167) *\end{array}$ & $\begin{array}{c}0.164884 \\
(0.455132) *\end{array}$ & $*$ & $\begin{array}{c}0.010128 \\
(0.441612) *\end{array}$ \\
\hline$M$ & & 1.0000 & $\begin{array}{c}0.708602 \\
(0.354261)^{*}\end{array}$ & $\begin{array}{c}-0.37024 \\
(0.463497)^{*} \\
\end{array}$ & $\begin{array}{c}0.196427 \\
(0.391622) * \\
\end{array}$ \\
\hline$\overline{D G D P}$ & & & 1.0000 & $*$ & $\begin{array}{c}0.209362 \\
(0.325124) *\end{array}$ \\
\hline$F R$ & & & & 1.0000 & $\begin{array}{c}-0.16926 \\
(0.410229)^{*}\end{array}$ \\
\hline$I N V$ & & & & & 1.0000 \\
\hline \multicolumn{6}{|c|}{ *Correlations are not performed between FR, CB and DGDP since CB and DGDP are components of FR. } \\
\hline \multicolumn{6}{|c|}{$* *$ Standard deviations in parentheses } \\
\hline \multicolumn{6}{|c|}{ Correlations taken over the full sample $1970-2002$ for all countries in the total sample } \\
\hline
\end{tabular}

\section{THE MODEL}

Using OLS on pool data has been shown in the literature to be a good way to get first pass point estimates. Several econometric analyses, for example those by Phillips and Moon (1999) and Pedroni (2000) have shown that OLS estimators are consistent with pool data. As $\mathrm{N}$ (the number of cross-sectional units) increases, however, the residual asymptotic bias increases.

The standard approach in the literature is to use a panel regression of the form:

$X_{i t}=\alpha F D_{i t}+\beta Z_{i t}+\mu_{i t}$

$\mathrm{X}$ represents the growth of per capita real GDP (this factor could also be a measure of the total factor productivity growth) in country $i$ at time t. The set of FD contains variables that represent financial development. This set comprises of CB, DGDP and M.

$\mathrm{Z}$ is a vector of conditioning variables, and usually includes other factors that theoretically affect economic growth. One of the factors in the set of $\mathrm{Z}$ may be the log of initial real GDP per capita. This factor measures the convergence effect. The literature has included such variables as the log of initial higher education enrollment as a measure of human capital, and the population growth rate. Other factors that are sometimes included here include the inflation rate, an export and import to real GDP ratio factor (to measure openness), etc. In the case of this paper, the set of $\mathrm{Z}$ is restricted to first four and then five variables - the log of initial lagged GDP per capita, GDP(-1), the degree of openness of the economy, OPEN, a measure of inflation, INF, a measure of real interest rates, RI, and a dummy variable for excess money growth, DM. GDP(-1) measures the convergence effect over time. OPEN (measured as the sum of foreign direct investment (FDI) and total credit from foreign sources ${ }^{1}$ ) indicates that the more open an economy, the greater the degree of economic development is expected to be, because the greater the potential for technology transfer and technology mimicry. As mentioned earlier, decreased openness is consistent with financial repression whereby domestic agents are restricted from foreign borrowing and lending. A greater degree of openness is therefore indicative of a lesser degree of financial repression. INF is the percentage change in the annual GDP deflator, and DM is set to capture excess money growth of over $10 \%$ per annum.

A priori, the null hypothesis is for $\alpha$ (the coefficient on financial development) is expected to differ depending on the proxy being used for financial development. When FD is restricted to CB, the null hypothesis for the overall sample is that $\alpha$ will be negatively and significantly related to growth (following the Chen-Fische (1993) paper. However this null hypothesis only holds with reference to the overall sample. (A discussion on what $\alpha$ is expected to be for the different geographical regions follows shortly.) When the FD vector is restricted to include $\mathrm{M}$ alone, the coefficient on $\alpha$ is expected to be positive for the overall sample and all sub-samples

\footnotetext{
${ }^{1}$ Sum of lines 78bed and 78bid from the IMF's International Financial Statistics.
} 
(following the implications of the King and Levine papers). Finally, when the FD vector is restricted to include DGDP alone, the coefficient on $\alpha$ is expected to be positive for the overall sample and all subs-samples.

In this paper, the basic methodology is transformed to include a financial repression variable, and a set of financial development variables as well as the vector of $Z$ variables. Equation (1) is then transformed to equation (2) below.

$X_{i t}=\delta F R_{i t}+\alpha F D_{i t}+\beta Z_{i t}+\mu_{i t}$

A priori, in equation 2 above, the $\delta$ variable is expected to differ in value depending on the sample being tested (the null hypotheses for $\delta$ for the sub-samples are discussed shortly). For the overall sample, the coefficient on $\delta$ is expected to be negative and significant following the theoretical implications described in section $3 \mathrm{~A}$. The null hypotheses for $\alpha$ are as described for equation 1 .

Several regression results are presented. First a broad regression (equation 1) for the entire sample period is examined to test for the overall relationship between finance and growth; financial repression is measured by RI. Thereafter, the regression is re-run for different geographical regions - Africa, Latin America and South-East Asia for the full sample period. Equation 2, where FD is measured by M and financial repression is measured by FR is then run on the broad sample and all the sub-samples.

For robustness purposes, a dummy variable is created for excess money growth (above 10\% per year) in all the thirty-three countries. The sample is thus split again to test the broad regression (including the dummy for money growth) for the different geographical areas. The regional grouping also serves to split countries according to according to whether they classify as "financially repressed" or "financially liberalized". This classification based on real interest rates is due to Pill and Pradhan (1997). On average the African countries exhibit the greatest degree of financial repression.

\section{RESULTS}

Table 4 (Appendix) presents the results of eight regressions on the entire sample period, 1970-2002, for the different groups of developing countries, with and without the DM variable. The proxy of choice in table 2 is the $\mathrm{CB}$ variable. The null hypothesis in regression 1 is that $\mathrm{CB}$ will be negatively related to growth. When the regression is run for all 32 countries (equation 1), the ratio of currency outside the banking system to GDP is significantly negative. The null hypothesis is accepted. Theory suggests (as discussed earlier) that this is indicative of a poorly developed financial system, which then translates into a poor link between savers and borrowers, and thus decreased efficiency in the savings-investment link, leading to lower real output.

However, as discussed earlier, overall results are not indicative of differences in the different geographical regions. Therefore the regression is then performed for the different country groupings. The statistical behavior of the CB ratio (as shown earlier) is that it displays a U-shape. The coefficient on CB is significant and negatively related to growth in equation 2, the sample of African countries, (as expected), again reflecting the poor state of financial sector development in these countries. The null hypothesis is again accepted here. In the Latin American regression (equation 3), the variable is not significant, although it is a negative coefficient. The null hypothesis thus cannot be accepted in the Latin American sample. South-East Asia (equation 4) has higher growth rates than the rest of the developing countries in this sample, and thus it is not surprising that the ratio is significantly (at the 5\% level) positively related to growth in this region (reflecting the right hand end of the $\mathrm{U}$ ). The South-East Asian countries have financial systems that are better developed and offer a more diverse array of financial instruments outside the banking sector to savers, and firms. The null hypothesis in equation 4 is that $\mathrm{CB}$ will be significantly positively related to growth, and the results for equation 4 shows that $\mathrm{CB}$ is indeed positively and significantly related to growth here and thus the null hypothesis is accepted here. Overall, the results indicate that the CB proxy does indeed fulfill the function of a measure of financial development that can capture the changing nature of the financial sector as a result of liberalization. 
With reference to the RI variable, it is expected that only in the countries that are financially repressed will the variable turn out to be significantly related to growth. The null hypothesis then states that RI will be negatively related to growth in the African sample only. As expected, only in African countries is the financial repression variable (RI) shown to negatively impact growth. The coefficient on this variable is negative and significant in this sample of countries. African countries have long experienced financial repression, which usually has been part of political repression, and it is only recently that some African countries have begun the process of liberalization of finance and trade. This finding echoes previous findings in the literature that indicate the excessive regulations and distortions in the financial market negatively impact the savings-investment link and thus negatively impact growth.

When the regressions are run with the dummy variable for excessive money growth included (Table 4 equation $1 b, 2 b, 3 b$ and $4 b$ ), the results show that excessive money growth negatively affects economic growth (without entering into the well-known and ongoing discussion about the causality between money and output). Indeed, the DM variable shows a significantly negative coefficient for all the samples (it is very close to the significance level for the South-East Asian countries), except for Latin America. In the Latin American sample, surprisingly, it very clearly shows a positive relationship. In Latin America, excess money growth seems to positively affect output. Further discussion on the effects of money growth on output differences is left for another study as the discussion best fits the money-output literature.

Theory predicts that the larger the monetary depth measure, the larger the size of the formal financial system, and thus the higher the rate of economic growth. Since M2 contains more developed savings instruments such as money market mutual funds and time deposits, it would indicate that there are other options for savers besides the basic checking and savings deposits. Mutual funds and time deposits may be offered by institutions other than the banking system and thus a high monetary depth ratio may exist simultaneously with a high currency outside the banking system ratio. Table 5 (Appendix) shows the results of the regression with the variable in the FD vector being $\mathrm{M}$ representing the size of the financial sector. When the regression is run for all countries in the sample together, the results indicate a strongly significant positive relationship between $\mathrm{M}$ and growth. The null hypothesis that $\mathrm{M}$ will strongly positively impact growth is accepted here. The results are less clear, however, when the region-specific results are analyzed. In the African group, the coefficient is both positive and insignificant, indicating that financial depth is not important in explaining growth. In the Latin American and South East Asian groups, the coefficient is negative in sign, but insignificant. In equations 2, 3 and 4 therefore, the null hypothesis that the formal size of the financial sector positively affects growth cannot be accepted.

Table 5 (Appendix) also displays the results for the same regression discussed above, but with the dummy for money growth included (equations $1 b, 2 b, 3 b$, and $4 b$ ). The results are robust to the inclusion of the dummy money does not seem to significantly relate to growth in all sub-sets of the samples. The results mirror those of Table 4, in that excessive money growth is shown to negatively impact economic growth in all the samples, except the Latin American group. The Latin American countries thus present something of a paradox - monetary depth seems to negatively affect growth, although the effect is very small, while excess money growth positively affects growth.

In Table 6 (Appendix), the basic model's FD vector in restricted to include the third proxy for financial development, DGDP. Theory suggests that DGDP should have a positive correlation with growth. The null hypothesis is then that DGDP will positively impact growth in the overall sample and all sub-samples. The overall regression presents a very strong positive correlation between DGDP and growth (the null is accepted here). On closer observation with the region-specific regressions, it becomes evident that this relationship is not uniform across all regional groupings. The relationship is strongly positive in the African group of countries, although the significance is lost when the dummy for excessive money growth is included. The savings-investment link is a more developed one in South East Asia and so the coefficient presents the expected positive value.

In the Latin American group of countries, the proxy displays an insignificant negative relationship. The null hypothesis is very significantly rejected here. A possible explanation could be related to the politico-economic and currency fluctuations within Latin America that has led to a preference for non-local currency based assets outside the banking sector (DeGregorio and Guidotti (1995) refer to the "extreme experiments of financial liberalization" in Latin America during the 1970s and 1980s, which then subsequently caused economic collapses). 
Regardless of the proxy for financial development being used, the dummy variable for excessive money growth consistently reflects a negative relationship between excess money growth and economic growth, except in Latin America. The Latin American group of countries therefore continues to display results that are diametrically opposite to those in the other regional splits.

Table 7 (Appendix) presents the results for the innovative approach where FR measures financial repression (as opposed to a more traditional measure where real interest rates proxy for financial repression). The FR variable is run simultaneously with the monetary depth variable $M$, which is used as a standard measure of the size of the formal financial sector. Recalling earlier findings, the FR ratio progressively decreased with financial liberalization. The null hypothesis for equations $1,1 b, 2$ and $2 b$ is that FR will be significantly and negatively related to growth.

The results strongly support the use of FR as a measure of financial repression, and justify the importance of controlling for financial repression as well as financial development when looking at the effect of finance on growth. FR turns out to be strongly negative in the overall regression, and moreover it is also strongly negative in the African sample of countries, which is more financially repressed than the other groups. The results are also robust to the inclusion of the dummy variable for excess money growth. In equations $3,3 \mathrm{~b}, 4$, and $4 \mathrm{~b}$ the null hypothesis changes and it is expected that FR will be positively and significantly related to growth. However, the evidence for this null hypothesis is not strong. In both the other two groups of countries, as expected (because they are more financially liberalized than Africa), the coefficient turns out to have a positive (albeit insignificant) relationship with growth. In this group of counties, there are better-developed savings channels outside the banking sector, and so the ratio of CB to DGDP would be lower. This is then consistent with the results from the regression analysis.

\section{CONCLUSION}

The relationship between finance and growth while theoretically sound is not unanimously agreed upon empirically. This paper looked at the relationship between financial development and growth while controlling for financial repression and geographical proximity. Currency outside the banking system relative to GDP (CB), broad money relative to GDP (M), and deposits within the banking sector relative to GDP (DGDP) are used as proxies for financial development. CB is a unique proxy in that it explains, to some extent, why there are so many different findings in the literature regarding the relationship between financial development and growth. These findings are very sensitive to the choice of proxy. The standard monetary depth measures may not be adequate in examining this relationship, because seigniorage can cause monetary depth to increase, falsely indicating financial sector development. It is also evident that monetary depth measures can increase in spite of the existence of financial repression, which indicates a paradoxical state of existence for an economy. CB reflects the development of the financial sector given the knowledge of the liberalization of the financial sector and the degree of financial repression. The results show that CB is related negatively to growth in the less liberalized developing countries and positively in the more liberalized developing countries.

Past studies have attempted to class countries on income levels, but the results in this paper indicate that even within developing countries, geographical (as well as socio-economic) proximity seems to be a factor in whether the relationship between financial development and growth differ. This finding has a very important implication in terms of development strategy. If countries that are close together are financially repressed, financial liberalization may not work to promote growth if the surrounding countries (especially the trading partners) are not financially liberalized as well. For example, land-locked countries rely on their partners with seaports for trade purposes. If the land-locked countries engage in liberalization, both financial and otherwise, but the neighboring seaport country does not, liberalization may not impact growth significantly. Needless to say, financial development must be part and parcel of a more comprehensive development package that targets all aspects of economic growth.

The results indicate that it is important to control for financial repression when looking at the relationship between financial development and growth. Traditionally financial repression is measured through the use of real interest rates. An innovative measure of financial repression (FR) combines the use of the ratio of currency outside banks to currency inside banks relative to GDP. In economies where there is a low level of financial sector 
liberalization, the ratio becomes particularly illuminative. The results show that countries with low levels of FR relative to the average are higher growth economies. In the African sub-sample of countries, FR is significantly negative in relation to economic growth. Surprisingly the results for all the financial development proxies seem to indicate that financial sector development has not been very important in explaining Latin American growth.

Further work needs to be done to identify a more complete measure of financial development. An ideal measure would encompass deregulation of the financial sector, size of the financial sector, and stock market development.

\section{AUTHOR INFORMATION}

Lillian Kamal is an assistant professor of Economics at the Barney School of Business in the University of Hartford. She holds a Ph.D. in Economics from West Virginia University, and Master's and Bachelor's Degrees in International Business Administration from the United States International University in Nairobi, Kenya. Lillian's research interests lie in macroeconomics, monetary economics and international economics. She focuses her research on how financial systems contribute to economic growth, social entrepreneurship and microfinance. E-mail: kamal@hartford.edu

\section{REFERENCES}

1. Andres, J., I. Hernando and D. Lopez-Salido, (1999), "The Role of the Financial System in the InflationGrowth Link", Banco de Espana - Servicio de Estudios, Working Papers.

2. Atje, R. and B. Jovanovic, (1993), "Stock Markets and Development", European Economic Review, vol. 37, issue 2-3, pages 632-640.

3. Beck, Thorsten and Levine, Ross. (2004) "Stock Markets, Banks, and Growth: Panel Evidence." Journal of Banking and Finance, March; 28 (3): 423-442.

4. Chen, L., and R. Fische, (1993), "Informal Financial Arrangements and the Stability of Deposit Insurance Schemes in Less Developed Countries", Southern Economic Journal, July; 60(1): 157-68.

5. Creane, S., R. Goyal, A. M. Mobarak, and R. Sab, (2003), "Financial Development and Economic Growth in the Middle East and North Africa", Newsletter of the Economic Research Forum, for the Arab Countries, Iran and Turkey, Volume 10, \# 2.

6. De Gregorio, J., and P. Guidotti, (1995), "Financial Development and Economic Growth”, World Development, vol. 23, issue 3, pages 433-448

7. Demetriades, P., and S. Andrianova, (2003), "Finance and Growth: What We Know and What We Need to Know" (with P. Demetriades), Discussion Papers in Economics No 03/15, University of Leicester, forthcoming in Charles Goodhart (ed.) Financial Development and Economic Growth: The Links, Routledge.

8. Evans, P. (1995), "How to estimate growth equations consistently." Mimeo, Ohio State University, 1995.

9. Fry, M. J., "Finance and Growth in Pacific Basin Developing Countries" (1996), Hermes-Niels; Lensink, Robert, eds. Financial development and economic growth: Theory and experiences from developing countries. Studies in Development Economics, vol. 6. London and New York: Routledge, pp. 138-58

10. Gelb, A. H., "Financial Policies, Growth, and Efficiency" (1989), Working Papers, The World Bank; Country Economics Department, Policy Research and External Affairs.

11. Giovanni Alberto, and Martha de Melo, (1993), "Government Revenue from Financial Repression", The American Economic Review, Vol. 83, no. 4, pp. 953-963.

12. Goldsmith, R. W., Financial Structure and Development. Yale University Press, New Haven, CT, 1969.

13. King, R. G. and Levine R. (1993a). "Finance and Growth: Schumpeter Might Be Right", Quarterly Journal of Economics, 108 (3), 717-737.

14. King, R. G. and Levine, R. (1993b). "Finance, Entrepreneurship, and Growth: Theory and Evidence", Journal of Monetary Economics, 32 (3), 513-542.

15. Levine, Ross. (1997). "Financial Development and Economic Growth: Views and Agenda", Journal of Economic Literature, 35, June, 688-726.

16. Levine, Ross and Zervos, Sara. (1998), "Stock Markets, Banks, and Economic Growth.” American Economic Review, June, 88(3), pp. 537-58. 
17. Lucas, R. E. (1988) 'On the mechanics of economic development'. Journal of Monetary Economics 22, 342.

18. McKinnon, R. I. Money and Capital in Economic Development, Washington, D.C.: Brookings Institution, 1973.

19. Pedroni, P. (2000) "Fully Modified OLS for Heterogeneous Cointegrated Panels" in Nonstationary Panels, Panel Cointegration and Dynamic Panels, Elsevier Science Inc., 15, 93-130.

20. Pesaran, H. and R. Smith (1995): Estimating Long-Run Relationships from Dynamic Heterogeneous Panels, Journal of Econometrics, 68, 79-113.

21. Phillips, C. B, and H. R. Moon, (1999), "Linear Regression Limit Theory for Nonstationary Panel Data", Econometrica, Vol. 67, No. 5, pp.1057-1111.

22. Pill, Huw and Mahmood Pradhan (1997). "Financial indicators and financial change: A comparison of Africa and Asia". Savings and Development 21 (2) (June).

23. Roubini, N. and Sala-i-Martin, X. (1992) 'Financial repression and economic growth', Journal of Development Economics 39, 5-30.

24. Shaw, E. S. Financial Deepening in Economic Development, New York: Oxford University Press, 1973.

25. Stern, N., (1989), “The Economics of Development: A Survey”, Economic Journal, vol. 99, issue 397, pages 597-685 


\section{Appendix: Table 4: Financial Development Proxy: CB}

\begin{tabular}{|c|c|c|c|c|c|c|c|c|}
\hline \multicolumn{9}{|c|}{ Dependent variable: Growth rate of real GDP per capita (sample period 1970-2002) } \\
\hline & \multicolumn{2}{|c|}{ All Countries } & \multicolumn{2}{|c|}{ Africa } & \multicolumn{2}{|c|}{ Latin America } & \multicolumn{2}{|c|}{ South-East Asia } \\
\hline & Eq. 1 & $E q .1 b$ & Eq. 2 & $E q .2 b$ & Eq. 3 & $E q .3 b$ & Eq. 4 & $E q .4 b$ \\
\hline $\mathrm{C}$ & $\begin{array}{c}2.402840 \\
(4.238417) * * *\end{array}$ & $\begin{array}{c}2.497646 \\
(4.433802) * *\end{array}$ & $\begin{array}{c}3.622998 \\
(4.331817) * *\end{array}$ & $\begin{array}{c}3.863590 \\
(4.675011) * *\end{array}$ & $\begin{array}{c}1.487037 \\
(1.201052) \\
\end{array}$ & $\begin{array}{c}1.001298 \\
(0.794060) \\
\end{array}$ & $\begin{array}{c}0.027234 \\
(0.007933) \\
\end{array}$ & $\begin{array}{c}0.639602 \\
(0.185950) \\
\end{array}$ \\
\hline GDP(-1) & $\begin{array}{c}-0.086363 \\
(1.643549) \\
\end{array}$ & $\begin{array}{c}-0.080851 \\
(-1.560567) \\
\end{array}$ & $\begin{array}{c}-0.022127 \\
(-0.243648) \\
\end{array}$ & $\begin{array}{c}-0.020850 \\
(-0.234756) \\
\end{array}$ & $\begin{array}{c}-0.012963 \\
(-0.247563) \\
\end{array}$ & $\begin{array}{c}-0.001267 \\
(-0.023326) \\
\end{array}$ & $\begin{array}{c}0.266323 \\
(0.448897) \\
\end{array}$ & $\begin{array}{c}0.191177 \\
(0.323917) \\
\end{array}$ \\
\hline RI & $\begin{array}{c}0.000694 \\
(1.096119) \\
\end{array}$ & $\begin{array}{c}0.000722 \\
(1.107688) \\
\end{array}$ & $\begin{array}{c}-0.043855 \\
(-1.547698)^{* *} \\
\end{array}$ & $\begin{array}{c}-0.052442 \\
(-1.887966) * * \\
\end{array}$ & $\begin{array}{c}0.000205 \\
(0.570795) \\
\end{array}$ & $\begin{array}{c}0.000164 \\
(0.483735) \\
\end{array}$ & $\begin{array}{c}0.014334 \\
(0.342875) \\
\end{array}$ & $\begin{array}{c}0.036147 \\
(0.873085) \\
\end{array}$ \\
\hline $\mathrm{CB}$ & $\begin{array}{c}-1.316516 \\
(-1.993393) * *\end{array}$ & $\begin{array}{c}-1.076274 \\
(1.677605) \\
\end{array}$ & $\begin{array}{c}-4.060607 \\
(-4.280970) * *\end{array}$ & $\begin{array}{c}-3.478344 \\
(-3.794612)^{* *}\end{array}$ & $\begin{array}{c}-1.077839 \\
(-0.498092) \\
\end{array}$ & $\begin{array}{c}-1.086889 \\
(-0.491527) \\
\end{array}$ & $\begin{array}{c}1.716058 \\
(2.163687)^{* *}\end{array}$ & $\begin{array}{c}1.882106 \\
(2.375579) *\end{array}$ \\
\hline INF & $\begin{array}{c}-0.006364 \\
(-2.135272)^{* *}\end{array}$ & $\begin{array}{c}-0.006512 \\
(2.145754) * * \\
\end{array}$ & $\begin{array}{c}-0.076707 \\
(-2.754965) * *\end{array}$ & $\begin{array}{c}-0.087384 \\
(-3.165435)^{* *}\end{array}$ & $\begin{array}{c}-\mathbf{- 0 . 0 0 4 0 1 5} \\
(-2.419554) * * \\
\end{array}$ & $\begin{array}{c}-\mathbf{- 0 . 0 0 3 7 0 7} \\
(-2.357813) * *\end{array}$ & $\begin{array}{c}-0.028419 \\
(-0.695895) \\
\end{array}$ & $\begin{array}{c}-0.035490 \\
(-0.895081) \\
\end{array}$ \\
\hline OPEN & $\begin{array}{c}0.232551 \\
(3.629416)^{* * *}\end{array}$ & $\begin{array}{c}0.235466 \\
(3.640161)^{* * *}\end{array}$ & $\begin{array}{c}0.184302 \\
(2.435591)^{* *}\end{array}$ & $\begin{array}{c}0.190586 \\
(2.526445)^{* *}\end{array}$ & $\begin{array}{c}0.186877 \\
(1.071609)\end{array}$ & $\begin{array}{c}0.193366 \\
(1.089477)\end{array}$ & $\begin{array}{c}0.194032 \\
(0.651251)\end{array}$ & $\begin{array}{c}0.233573 \\
(0.861263)\end{array}$ \\
\hline DM & & $\begin{array}{c}-1.543206 \\
(3.315909)^{* *} \\
\end{array}$ & & $\begin{array}{c}-2.489706 \\
(-3.987366) * * \\
\end{array}$ & & $\begin{array}{c}1.767749 \\
(2.021807)^{* * *} \\
\end{array}$ & & $\begin{array}{c}-2.343405 \\
(-2.843786)^{* *} \\
\end{array}$ \\
\hline $\begin{array}{l}\text { Adjusted } \\
\text { R-squared }\end{array}$ & 0.03 & 0.04 & 0.06 & 0.09 & 0.03 & 0.05 & 0.05 & 0.09 \\
\hline \multicolumn{9}{|c|}{ t-statistics in parentheses are White's heteroskedasticity-consistent t-statistics. $* *$ t statistics significant at $1 \% \quad *$ t-statistics significant at $5 \%$} \\
\hline \multicolumn{9}{|c|}{ The dependent variable is the growth rate of real GDP per capita } \\
\hline \multicolumn{9}{|c|}{ GDP(-1) is the initial level of real GDP } \\
\hline \multicolumn{9}{|c|}{ RI is real interest rates calculated according to the Fisher Identity } \\
\hline \multicolumn{9}{|c|}{ CB is the ratio of currency outside the banking sector to GDP (both numerator and denominator are in nominal values) } \\
\hline \multicolumn{9}{|c|}{ INF is the annual rate of increase in the GDP deflator } \\
\hline \multicolumn{9}{|c|}{ OPEN is the sum of lines 78 bed and 78 bid from the IMF's IFS database } \\
\hline \multirow{2}{*}{\multicolumn{9}{|c|}{ DM is the dummy variable for excess money growth (measured as annual rates of growth of $10 \%$ or more) }} \\
\hline SI & (1) & & & & & & & \\
\hline
\end{tabular}




\section{Appendix: Table 5: Financial Development Proxy: M}

\begin{tabular}{|c|c|c|c|c|c|c|c|c|}
\hline \multicolumn{9}{|c|}{ Dependent variable: Growth rate of real GDP per capita (sample period 1970-2002) } \\
\hline & \multicolumn{2}{|c|}{ All Countries } & \multicolumn{2}{|c|}{ Africa } & \multicolumn{2}{|c|}{ Latin America } & \multicolumn{2}{|c|}{ South-East Asia } \\
\hline & Eq. 1 & $E q .1 b$ & $E q .2$ & $E q .2 b$ & $E q .3$ & $E q .3 b$ & Eq. 4 & $E q .4 b$ \\
\hline $\mathrm{C}$ & $\begin{array}{c}1.097327 \\
(1.962020) *\end{array}$ & $\begin{array}{c}1.330951 \\
(2.394463)^{* * *}\end{array}$ & $\begin{array}{c}2.186075 \\
(2.633742) * *\end{array}$ & $\begin{array}{c}2.762327 \\
(3.376482) * *\end{array}$ & $\begin{array}{c}1.578440 \\
(0.959037) \\
\end{array}$ & $\begin{array}{c}0.857516 \\
(0.522489) \\
\end{array}$ & $\begin{array}{c}-4.471848 \\
(-) \\
\end{array}$ & $\begin{array}{c}-4.086026 \\
(-1.025948) \\
\end{array}$ \\
\hline GDP(-1) & $\begin{array}{c}-0.078761 \\
(-1.447729) \\
\end{array}$ & $\begin{array}{c}-0.073268 \\
(-1.368622) \\
\end{array}$ & $\begin{array}{c}-0.116984 \\
(-1.254001) \\
\end{array}$ & $\begin{array}{c}-0.102150 \\
(-1.128735) \\
\end{array}$ & $\begin{array}{c}-0.017674 \\
(-0.303524) \\
\end{array}$ & $\begin{array}{c}-0.002469 \\
(-0.041562) \\
\end{array}$ & $\begin{array}{c}1.207814 \\
(1.520176) \\
\end{array}$ & $\begin{array}{c}1.186918 \\
(1.659666) \\
\end{array}$ \\
\hline RI & $\begin{array}{c}0.000523 \\
(0.969460) \\
\end{array}$ & $\begin{array}{c}0.000597 \\
(1.004008) \\
\end{array}$ & $\begin{array}{c}-0.027686 \\
(-0.979989) \\
\end{array}$ & $\begin{array}{c}-0.039910 \\
(-1.453725) \\
\end{array}$ & $\begin{array}{c}0.000199 \\
(0.572773) \\
\end{array}$ & $\begin{array}{c}0.000141 \\
(0.436297) \\
\end{array}$ & $\begin{array}{c}0.025053 \\
(0.937132) \\
\end{array}$ & $\begin{array}{l}0.035939 \\
(0.80053) \\
\end{array}$ \\
\hline M & $\begin{array}{c}0.021621 \\
(2.209510) * *\end{array}$ & $\begin{array}{c}0.018553 \\
(2.052905)^{* *}\end{array}$ & $\begin{array}{c}0.001953 \\
(0.174695) \\
\end{array}$ & $\begin{array}{c}-0.000910 \\
(-0.083315) \\
\end{array}$ & $\begin{array}{c}-0.023464 \\
(-0.400281) \\
\end{array}$ & $\begin{array}{c}-0.013700 \\
(-0.234294) \\
\end{array}$ & $\begin{array}{c}0.019234 \\
(0.937132) \\
\end{array}$ & $\begin{array}{c}-0.013934 \\
(-0.654882) \\
\end{array}$ \\
\hline INF & $\begin{array}{c}-\mathbf{- 0 . 0 0 5 3 9 7} \\
(-2.083833) * * \\
\end{array}$ & $\begin{array}{c}-0.005818 \\
(-2.095472)^{* *}\end{array}$ & $\begin{array}{c}-\mathbf{- 0 . 0 6 6 8 1 3} \\
(-2.398854) * * \\
\end{array}$ & $\begin{array}{c}-0.080594 \\
(-2.929133) * * \\
\end{array}$ & $\begin{array}{c}-\mathbf{- 0 . 0 0 4 1 3 8} \\
(-2.410565) * * \\
\end{array}$ & $\begin{array}{c}-\mathbf{- 0 . 0 0 3 7 1 1} \\
(-2.306539) * *\end{array}$ & $\begin{array}{c}-0.035703 \\
(-0.793163) \\
\end{array}$ & $\begin{array}{c}-0.039782 \\
(-0.886310) \\
\end{array}$ \\
\hline OPEN & $\begin{array}{c}0.217895 \\
(3.652071)^{* *}\end{array}$ & $\begin{array}{c}0.218359 \\
(3.656869)^{* *}\end{array}$ & $\begin{array}{c}0.235007 \\
(3.013396)^{* *}\end{array}$ & $\begin{array}{c}0.234693 \\
(2.955254)^{* *}\end{array}$ & $\begin{array}{c}0.236599 \\
(1.187606)\end{array}$ & $\begin{array}{c}0.226927 \\
(1.126206)\end{array}$ & $\begin{array}{c}-0.947164 \\
(-1.298190)\end{array}$ & $\begin{array}{c}-0.801312 \\
(-1.157026)\end{array}$ \\
\hline $\mathrm{DM}$ & & $\begin{array}{c}-1.473281 \\
(-3.131815)^{* *} \\
\end{array}$ & & $\begin{array}{c}-2.761851 \\
(-4.263707)^{* *} \\
\end{array}$ & & $\begin{array}{c}1.747466 \\
(1.978409) * \\
\end{array}$ & & $\begin{array}{c}-1.313294 \\
(-1.767505) \\
\end{array}$ \\
\hline $\begin{array}{l}\text { Adjusted } \\
\text { R-squared }\end{array}$ & 0.03 & 0.04 & 0.04 & 0.08 & 0.06 & 0.08 & 0.06 & 0.08 \\
\hline \multicolumn{9}{|c|}{ t-statistics in parentheses are White's heteroskedasticity-consistent t-statistics. $* *$ t statistics significant at $1 \% \quad *$ t-statistics significant at $5 \%$} \\
\hline \multicolumn{9}{|c|}{ The dependent variable is the growth rate of real GDP per capita } \\
\hline \multicolumn{9}{|c|}{ GDP(-1) is the initial level of real GDP } \\
\hline \multicolumn{9}{|c|}{ RI is real interest rates calculated according to the Fisher Identity } \\
\hline \multicolumn{9}{|c|}{$\mathrm{M}$ is the ratio of M2 to GDP (both numerator and denominator are in nominal values) } \\
\hline \multicolumn{9}{|c|}{ INF is the annual rate of increase in the GDP deflator } \\
\hline \multicolumn{9}{|c|}{ OPEN is the sum of lines 78 bed and 78 bid from the IMF's IFS database } \\
\hline \multicolumn{9}{|c|}{ DM is the dummy variable for excess money growth (measured as annual rates of growth of $10 \%$ or more) } \\
\hline \multicolumn{9}{|c|}{ Ho: $\mathrm{M}$ is significantly and positively related to growth in all equations. } \\
\hline
\end{tabular}




\section{Appendix: Table 6: Financial Development Proxy: DGDP}

\begin{tabular}{|c|c|c|c|c|c|c|c|c|}
\hline \multicolumn{9}{|c|}{ Dependent variable: Growth rate of real GDP per capita (sample period 1970-2002) } \\
\hline & \multicolumn{2}{|c|}{ All Countries } & \multicolumn{2}{|c|}{ Africa } & \multicolumn{2}{|c|}{ Latin America } & \multicolumn{2}{|c|}{ South-East Asia } \\
\hline $\mathrm{C}$ & $\begin{array}{c}0.636714 \\
(1.241928)\end{array}$ & $\begin{array}{c}0.936228 \\
(1.808273)\end{array}$ & $\begin{array}{c}1.209627 \\
(1.561390)\end{array}$ & $\begin{array}{c}1.906548 \\
(2.522122)^{* *}\end{array}$ & $\begin{array}{c}2.539142 \\
(1.721417)\end{array}$ & $\begin{array}{c}1.551427 \\
(1.038724)\end{array}$ & $\begin{array}{c}-4.301630 \\
(-0.978343)\end{array}$ & $\begin{array}{c}-4.041315 \\
(-0.918312)\end{array}$ \\
\hline GDP(-1) & $\begin{array}{c}-0.064303 \\
(-1.211474)\end{array}$ & $\begin{array}{c}-0.061765 \\
(-1.169097)\end{array}$ & $\begin{array}{c}-0.084639 \\
(-0.916133)\end{array}$ & $\begin{array}{c}-0.076104 \\
(-0.849309)\end{array}$ & $\begin{array}{c}-0.038331 \\
(-0.643008)\end{array}$ & $\begin{array}{c}-0.017261 \\
(-0.282304)\end{array}$ & $\begin{array}{c}1.194265 \\
(1.435496)\end{array}$ & $\begin{array}{c}1.199878 \\
(1.447809)\end{array}$ \\
\hline RI & $\begin{array}{c}0.000530 \\
(0.964697)\end{array}$ & $\begin{array}{c}0.000602 \\
(0.999707) \\
\end{array}$ & $\begin{array}{c}-0.027878 \\
(-0.996244)\end{array}$ & $\begin{array}{c}-0.039414 \\
(-1.447283) *\end{array}$ & $\begin{array}{c}0.000205 \\
(0.619666)\end{array}$ & $\begin{array}{c}0.000150 \\
(0.479863) \\
\end{array}$ & $\begin{array}{c}0.020300 \\
(0.479035)\end{array}$ & $\begin{array}{c}0.032448 \\
(0.744155)\end{array}$ \\
\hline DGDP & $\begin{array}{c}4.235514 \\
(3.859902) * *\end{array}$ & $\begin{array}{c}3.547707 \\
(3.498062)^{* *}\end{array}$ & $\begin{array}{c}3.995771 \\
(2.931631)^{* *}\end{array}$ & $\begin{array}{c}3.090618 \\
(2.336447)^{* * *}\end{array}$ & $\begin{array}{c}-6.197412 \\
(-1.265309) \\
\end{array}$ & $\begin{array}{c}-4.003871 \\
(-0.820124) \\
\end{array}$ & $\begin{array}{l}2.2126635 \\
(0.929172) \\
\end{array}$ & $\begin{array}{c}1.338871 \\
(0.586651)\end{array}$ \\
\hline INF & $\begin{array}{c}-0.005533 \\
(-2.101259) * *\end{array}$ & $\begin{array}{c}-0.005923 \\
(-2.112104) * *\end{array}$ & $\begin{array}{c}-\mathbf{- 0 . 0 6 5 7 5 3} \\
(-2.393286) * * \\
\end{array}$ & $\begin{array}{c}-\mathbf{0 . 0 7 8 8 3 0} \\
(-2.900402)^{* *}\end{array}$ & $\begin{array}{c}-0.004085 \\
(-2.617976) * *\end{array}$ & $\begin{array}{c}-\mathbf{- 0 . 0 0 3 7 1 8} \\
(-2.502373) * * \\
\end{array}$ & $\begin{array}{c}-0.040323 \\
(-0.930369) \\
\end{array}$ & $\begin{array}{c}-0.043319 \\
(-1.005860) \\
\end{array}$ \\
\hline OPEN & $\begin{array}{c}0.198033 \\
(3.487750) * * \\
\end{array}$ & $\begin{array}{c}0.201842 \\
(3.540653) * * \\
\end{array}$ & $\begin{array}{c}0.219762 \\
(2.953599)^{* *}\end{array}$ & $\begin{array}{c}.222280 \\
(2.921568)^{* *}\end{array}$ & $\begin{array}{c}0.265529 \\
(1.454114) \\
\end{array}$ & $\begin{array}{c}0.247526 \\
(1.339211) \\
\end{array}$ & $\begin{array}{c}-0.945962 \\
(-1.323640) \\
\end{array}$ & $\begin{array}{c}-0.791210 \\
(-1.184242) \\
\end{array}$ \\
\hline DM & & $\begin{array}{c}-1.356186 \\
(-2.891030) * * \\
\end{array}$ & & $\begin{array}{c}-2.638875 \\
(-4.118925)^{* *} \\
\end{array}$ & & $\begin{array}{c}1.610828 \\
(1.813922) \\
\end{array}$ & & $\begin{array}{c}-1.295045 \\
(-1.816502)^{* *} \\
\end{array}$ \\
\hline $\begin{array}{l}\text { Adjusted } \\
\text { R-squared }\end{array}$ & 0.04 & 0.05 & 0.05 & 0.08 & 0.06 & 0.08 & 0.06 & 0.10 \\
\hline \multicolumn{9}{|c|}{ t-statistics in parentheses are White's heteroskedasticity-consistent t-statistics. $* *$ t statistics significant at $1 \% \quad *$ t-statistics significant at $5 \%$} \\
\hline \multicolumn{9}{|c|}{ The dependent variable is the growth rate of real GDP per capita } \\
\hline \multicolumn{9}{|c|}{ GDP(-1) is the initial level of real GDP } \\
\hline \multicolumn{9}{|c|}{ RI is real interest rates calculated according to the Fisher Identity } \\
\hline \multicolumn{9}{|c|}{ DGDP is the ratio of banking sector deposits to GDP (both numerator and denominator are in nominal values) } \\
\hline \multicolumn{9}{|c|}{ INF is the annual rate of increase in the GDP deflator } \\
\hline \multicolumn{9}{|c|}{ OPEN is the sum of lines 78 bed and 78 bid from the IMF's IFS database } \\
\hline \multicolumn{9}{|c|}{ DM is the dummy variable for excess money growth (measured as annual rates of growth of $10 \%$ or more) } \\
\hline \multicolumn{9}{|c|}{ Ho: DGDP is significantly and positively related to growth in all equations. } \\
\hline
\end{tabular}




\section{Appendix: Table 7: Financial Repression Variable: FR; Financial Development Proxy: M}

\begin{tabular}{|c|c|c|c|c|c|c|c|c|}
\hline \multicolumn{9}{|c|}{ Dependent variable: Growth rate of real GDP per capita (sample period 1970-2002) } \\
\hline & \multicolumn{2}{|c|}{ All Countries } & \multicolumn{2}{|c|}{ Africa } & \multicolumn{2}{|c|}{ Latin America } & \multicolumn{2}{|c|}{ South-East Asia } \\
\hline $\mathrm{C}$ & $\begin{array}{c}1.568717 \\
(2.535314)^{* *} \\
\end{array}$ & $\begin{array}{c}1.719512 \\
(2.787565)^{* *} \\
\end{array}$ & $\begin{array}{c}2.616355 \\
(3.080592) * * \\
\end{array}$ & $\begin{array}{c}2.952499 \\
(3.522414)^{* *} \\
\end{array}$ & $\begin{array}{c}0.148234 \\
(0.083066) \\
\end{array}$ & $\begin{array}{c}-0.231335 \\
(-0.128523) \\
\end{array}$ & $\begin{array}{c}-1.121635 \\
(-0.300035) \\
\end{array}$ & $\begin{array}{c}-1.011934 \\
(-0.274872) \\
\end{array}$ \\
\hline GDP $(-1)$ & $\begin{array}{c}-0.023173 \\
(-0.467828) \\
\end{array}$ & $\begin{array}{c}-0.025713 \\
(-0.526762) \\
\end{array}$ & $\begin{array}{c}0.056253 \\
(0.604061) \\
\end{array}$ & $\begin{array}{c}0.034495 \\
(0.379528) \\
\end{array}$ & $\begin{array}{c}-0.016851 \\
(-0.286443) \\
\end{array}$ & $\begin{array}{c}-0.002661 \\
(-0.044487) \\
\end{array}$ & $\begin{array}{c}0.760507 \\
(1.133501) \\
\end{array}$ & $\begin{array}{c}0.801135 \\
(1.233191) \\
\end{array}$ \\
\hline FR & $\begin{array}{c}-\mathbf{- 0 . 1 5 8 6 0 3} \\
(-2.708823) * *\end{array}$ & $\begin{array}{c}-0.136280 \\
(-2.359584) * *\end{array}$ & $\begin{array}{c}-\mathbf{- 0 . 2 3 9 3 9 3} \\
(-3.475372)^{* *}\end{array}$ & $\begin{array}{c}-\mathbf{- 0 . 1 9 5 2 3 9} \\
(-2.860332)^{* *}\end{array}$ & $\begin{array}{c}0.359880 \\
(1.256131) \\
\end{array}$ & $\begin{array}{c}0.285001 \\
(0.993561) \\
\end{array}$ & $\begin{array}{c}0.055648 \\
(0.299931) \\
\end{array}$ & $\begin{array}{c}0.136621 \\
(0.693468) \\
\end{array}$ \\
\hline M & $\begin{array}{c}\mathbf{0 . 0 0 8 6 1 7} \\
(\mathbf{0 . 8 4 6 7 5 3 )} \\
\end{array}$ & $\begin{array}{c}0.009156 \\
(0.911235) \\
\end{array}$ & $\begin{array}{c}-0.026053 \\
(-1.930438) \\
\end{array}$ & $\begin{array}{c}-0.022919 \\
(-1.721531) \\
\end{array}$ & $\begin{array}{c}0.004461 \\
(0.076646) \\
\end{array}$ & $\begin{array}{c}0.007663 \\
(0.131046) \\
\end{array}$ & $\begin{array}{c}-0.022557 \\
(-0.865526) \\
\end{array}$ & $\begin{array}{c}-0.026591 \\
(-1.045750) \\
\end{array}$ \\
\hline INF & $\begin{array}{c}-0.004388 \\
(-4.265032) * * \\
\end{array}$ & $\begin{array}{c}-0.004503 \\
(-4.253011) * * \\
\end{array}$ & $\begin{array}{c}-0.050525 \\
(-3.650035) * * \\
\end{array}$ & $\begin{array}{c}-0.053506 \\
(-3.888519) * * \\
\end{array}$ & $\begin{array}{c}-0.003321 \\
(-5.627219) * * \\
\end{array}$ & $\begin{array}{c}-0.003126 \\
(-5.261700) * * \\
\end{array}$ & $\begin{array}{c}-0.042895 \\
(-0.959747) \\
\end{array}$ & $\begin{array}{c}-0.057499 \\
(-1.288916)^{* * *} \\
\end{array}$ \\
\hline OPEN & $\begin{array}{c}0.216454 \\
(3.657397)^{* * *} \\
\end{array}$ & $\begin{array}{c}0.219822 \\
(3.684691)^{* *} \\
\end{array}$ & $\begin{array}{c}0.218746 \\
(2.843832)^{* *} \\
\end{array}$ & $\begin{array}{c}0.222573 \\
(2.849249) * * \\
\end{array}$ & $\begin{array}{c}0.241603 \\
(1.204409) \\
\end{array}$ & $\begin{array}{c}0.231439 \\
(1.141297) \\
\end{array}$ & $\begin{array}{c}0.249325 \\
(-0.872533) \\
\end{array}$ & $\begin{array}{c}0.286616 \\
(1.100273) \\
\end{array}$ \\
\hline DM & & $\begin{array}{c}-1.381757 \\
(-2.955714) * * \\
\end{array}$ & & $\begin{array}{c}-2.359342 \\
(-3.814242)^{* *} \\
\end{array}$ & & $\begin{array}{c}1.663402 \\
(1.887061) \\
\end{array}$ & & $\begin{array}{c}-2.371291 \\
(-2.912096)^{* *}\end{array}$ \\
\hline $\begin{array}{l}\text { Adjusted } \\
\text { R-squared }\end{array}$ & 0.04 & 0.05 & 0.06 & 0.08 & 0.04 & 0.06 & 0.04 & 0.08 \\
\hline \multicolumn{9}{|c|}{ t-statistics in parentheses are White's heteroskedasticity-consistent t-statistics. **t statistics significant at $1 \%$} \\
\hline \multicolumn{9}{|c|}{ The dependent variable is the growth rate of real GDP per capita } \\
\hline \multicolumn{9}{|c|}{ GDP(-1) is the initial level of real GDP } \\
\hline \multicolumn{9}{|c|}{ FR is the ratio of CB to DGDP (both numerator and denominator are in nominal values) } \\
\hline \multicolumn{9}{|c|}{$\mathrm{M}$ is the ratio of M2 to GDP (both numerator and denominator are in nominal values) } \\
\hline \multicolumn{9}{|c|}{ INF is the annual rate of increase in the GDP deflator } \\
\hline \multicolumn{9}{|c|}{ OPEN is the sum of lines 78 bed and 78 bid from the IMF's IFS database } \\
\hline \multicolumn{9}{|c|}{ DM is the dummy variable for excess money growth (measured as annual rates of growth of $10 \%$ or more) } \\
\hline \multicolumn{9}{|c|}{ Ho: $\mathrm{M}$ is significantly and positively related to growth in all equations. } \\
\hline & & & & & & & & \\
\hline
\end{tabular}

